\title{
FXTAS is rare among Portuguese patients with movement disorders: FMR1 premutations may be associated with a wider spectrum of phenotypes
}

\author{
Ana I Seixas ${ }^{1}$, José Vale ${ }^{2}$, Paula Jorge ${ }^{3}$, Isabel Marques ${ }^{3}$, Rosário Santos ${ }^{3}$, Isabel Alonso ${ }^{1}$, Ana M Fortuna ${ }^{3}$, \\ Jorge Pinto-Basto ${ }^{1,6}$, Paula Coutinho ${ }^{4}$, Russell L Margolis ${ }^{5}$, Jorge Sequeiros ${ }^{1,6}$ and Isabel Silveira ${ }^{1 *}$
}

\begin{abstract}
The fragile X-associated tremor/ataxia syndrome (FXTAS) is a late-onset neurodegenerative disorder caused by expansions of 55-200 CGG repeats in the 5'UTR of the FMR1 gene. These FMR1 premutation expansions have relatively high frequency in the general population. To estimate the frequency of FMR1 premutations among Portuguese males with non-familial, late-onset movement disorders of unknown etiology, we assessed CGG repeat size in males with disease onset after the age of 50 and negative or unknown family history for late-onset movement disorders, who were sent for SCA, HD, or PD genetic testing at a reference laboratory. The selected patients had a primary clinical diagnosis based on one of the following cardinal features of FXTAS: ataxia, tremor, or cognitive decline. A total of 86 subjects were genotyped for the CGG repeat in the FMR1 gene. We detected one patient with an expansion in the premutation range. The frequency of FMR1 premutations was $1.9 \%(1 / 54)$ in our group of patients with ataxia as the primary clinical feature, and 1.2\% (1/86) in the larger movement disorders group. In the family of the FXTAS case, premutation-transmitting females presented a history of psychiatric symptoms, suggesting that, given the wide phenotypical expression of the premutation in females, neuropsychiatric surveillance is necessary. In conclusion, genetic testing for FXTAS should be made available to patients with adult-onset movement disorders to enable adequate genetic counseling to family members.
\end{abstract}

\section{Findings}

Expansions of a CGG repeat tract in the 5'UTR region of the FMR1 gene causes the fragile X syndrome (FXS), the most common inherited cause of mental retardation. FXS is an X-linked disorder, characterized by moderate to severe mental impairment, facial dysmorphism and behavioral abnormalities in males, and by milder symptoms in some carrier females [1]. Full mutations (more than 200 CGGs) cause FXS, as they lead to loss of function due to gene silencing mediated by abnormal methylation patterns $[2,3]$. Normal alleles range in length from 5 to 44 triplets, and repeats of 45-54 CGGs are "grey zone alleles" of unknown biological significance [4]. Premutations range from 55 to 200 CGGs and have been associated with two different phenotypes: females are at

\footnotetext{
* Correspondence: isilveir@ibmc.up.pt

'UnIGENe, IBMC - Instituto de Biologia Molecular e Celular, Universidade do Porto, Porto, Portugal

Full list of author information is available at the end of the article

a higher risk for premature ovarian insufficiency (POI) [5]; whereas males may be affected by the fragile $\mathrm{X}$-associated tremor/ataxia syndrome (FXTAS) [6,7].

FXTAS is characterized by progressive cerebellar ataxia, tremor, and parkinsonism with bradikynesia and rigidity; other symptoms may include cognitive decline and peripheral neuropathy [8]. Neuroradiological findings show generalized brain atrophy with white matter lesions in the middle cerebellar peduncle $[9,10]$. Clinical criteria for FXTAS were proposed by Hagerman et al. [11]: presence of a FMR1 premutation, one major clinical sign (gait ataxia or intention tremor), and one major finding on neuroimaging (white matter lesions in middle cerebellar peduncles). Histopathology of FXTAS postmortem brains revealed loss of Purkinje cells in the cerebellum, and presence of eosinophilic intranuclear inclusions in neurons and astrocytes of the cortex [12]. The pathogenic mechanism of FXTAS seems to be different from that of FXS: abnormal methylation does not 
occur with premutation and, therefore, a loss of function mechanism is unlikely. Instead, it appears to be associated with toxic RNA species containing long CGG tracts [13].

Penetrance of FXTAS in males carrying FMR1 premutations increases from $17 \%$ in the sixth decade to $75 \%$ after the age of 80 . FXTAS in females has been reported $[14,15]$, but appears to be rare. Though only $1 / 4000$ men have the full mutation, frequency of premutations is much greater: $1 / 1000$ in Caucasian males [16]. The high frequency of FMR1 premutations in the general population was taken as an indication that they could represent a major cause of non-familial cases of lateonset ataxia. A review of the literature reported that the frequency of $F M R 1$ premutations, in all combined ataxia cases, was $1.3 \%$ in men and $0.24 \%$ in women [17]. As ataxia in FXTAS is often associated with tremor and/or cognitive decline, it is plausible that some cases of FXTAS could present for testing with a clinical diagnosis other than cerebellar ataxia; therefore, other movement disorders have also been screened for FMR1 premutations. The combination of all studies published up to 2008, in patients with movement disorders other than ataxia (including essential tremor, parkinsonism, and multiple system atrophy), gives a total frequency of CGG repeat length in the FXTAS range of $0.37 \%$, higher than the overall population rate [17].

Here, we present the first study on the frequency of FMR1 premutations in a sample of Portuguese males sent for genetic testing, with late-onset movement disorders characterized by one or more of the FXTAS cardinal clinical features (ataxia, tremor, or cognitive decline). Additionally, we investigated transmission of the FMR1 repeat among FXTAS family relatives.

Cases were ascertained from a pool of patients referred to a reference laboratory in Portugal for genetic testing for neurological diseases. Inclusion criteria were as follows: males with onset after age 50 years, absent or unknown family history of autosomal dominant lateonset movement disorders, clinical diagnosis of lateonset movement disorder (spinocerebellar ataxia, SCA; Huntington disease, HD; or Parkinson disease, PD), and absence of SCA, HD, or relevant PD mutations. Only those presenting with ataxia, parkinsonism, and/or cognitive decline were included. Genomic DNA was isolated from peripheral blood using standard techniques. All patients gave their informed consent. Assessment of $(\mathrm{CGG})_{\mathrm{n}}$ in FMR1 was performed by PCR, improved for amplification of GC-rich sequence regions, as described previously [18]. PCR products were visualized on agarose gel stained with ethidium bromide and compared to a control with 30 CGGs; PCR products that appeared larger were further analyzed by automated fragment analysis in a 3730xl DNA Analyzer (Applied Biosystems, Foster City, CA) for assessment of repeat number. Premutation status was established for alleles with 55-200 CGGs. Full mutations were detected by double digestion with EcoRI and EagI of $10 \mu \mathrm{g}$ of genomic DNA, followed by electrophoresis in agarose gels and blotting onto Hybond N+ membranes (Amersham, UK). Probe Ox1.9 was labeled by $\mathrm{P}^{32}$-dCTP nick translation and hybridized according to standard methodology. Autoradiography was carried out for $24-48$ hours at $-70^{\circ} \mathrm{C}$, using intensifying screens and Kodak X-Omat-RP films.

A total of 86 male patients were identified as candidates, following application of the defined criteria. Demographics and clinical features are summarized in Table 1; 54/86 patients (63\%) had ataxia, and 50/86 (58\%) had no known family history of late-onset movement disorders. We identified one patient with approximately 95 CGGs. Frequency of premutations in the total sample was $1.2 \%$. In the subset of patients with ataxia, frequency was $1.9 \%$.

The patient carrying the FMR1 premutated allele was a 73-year-old male, who reported onset at age 51, and was sent for genetic testing of SCAs (Figure 1). He had an initial clinical diagnosis of essential tremor that did not improve upon treatment with beta-blockers and antiepileptic drugs. Further examination at age 66 revealed a mild cerebellar syndrome with gait ataxia and dysarthria, difficulties with memory and executive function, and neurosensorial deafness. MRI showed diffuse atrophy of the cerebellum and cerebellar peduncles. At age 72 , the patient presented with aggravated cognitive

Table 1 Demographics and clinical features of the patient population

\begin{tabular}{|c|c|c|c|c|}
\hline & \multicolumn{3}{|c|}{ Cardinal clinical feature } & \multirow[b]{2}{*}{$\begin{array}{c}\text { Total } \\
(\mathrm{N}=86)\end{array}$} \\
\hline & $\begin{array}{l}\text { Ataxia } \\
(\mathrm{n}=54)\end{array}$ & $\begin{array}{l}\text { Tremor } \\
(\mathrm{n}=4)\end{array}$ & $\begin{array}{c}\text { Cognitive deficits } \\
(n=28)\end{array}$ & \\
\hline Age (mean \pm SD) & $67.7 \pm 9.1$ & $59.0 \pm 8.6$ & $70.0 \pm 9.2$ & $68.0 \pm 9.3$ \\
\hline Age-of-onset (mean \pm SD) & $59.0 \pm 6.8$ & $54.0 \pm 1.4$ & $60.5 \pm 6.7$ & $59.2 \pm 6.7$ \\
\hline With additional cardinal features $(n)$ & 13 & 1 & 4 & 18 \\
\hline \multicolumn{5}{|l|}{ Family history $(n)$} \\
\hline None & 33 & 3 & 14 & 50 \\
\hline Unknown & 21 & 1 & 14 & 36 \\
\hline
\end{tabular}




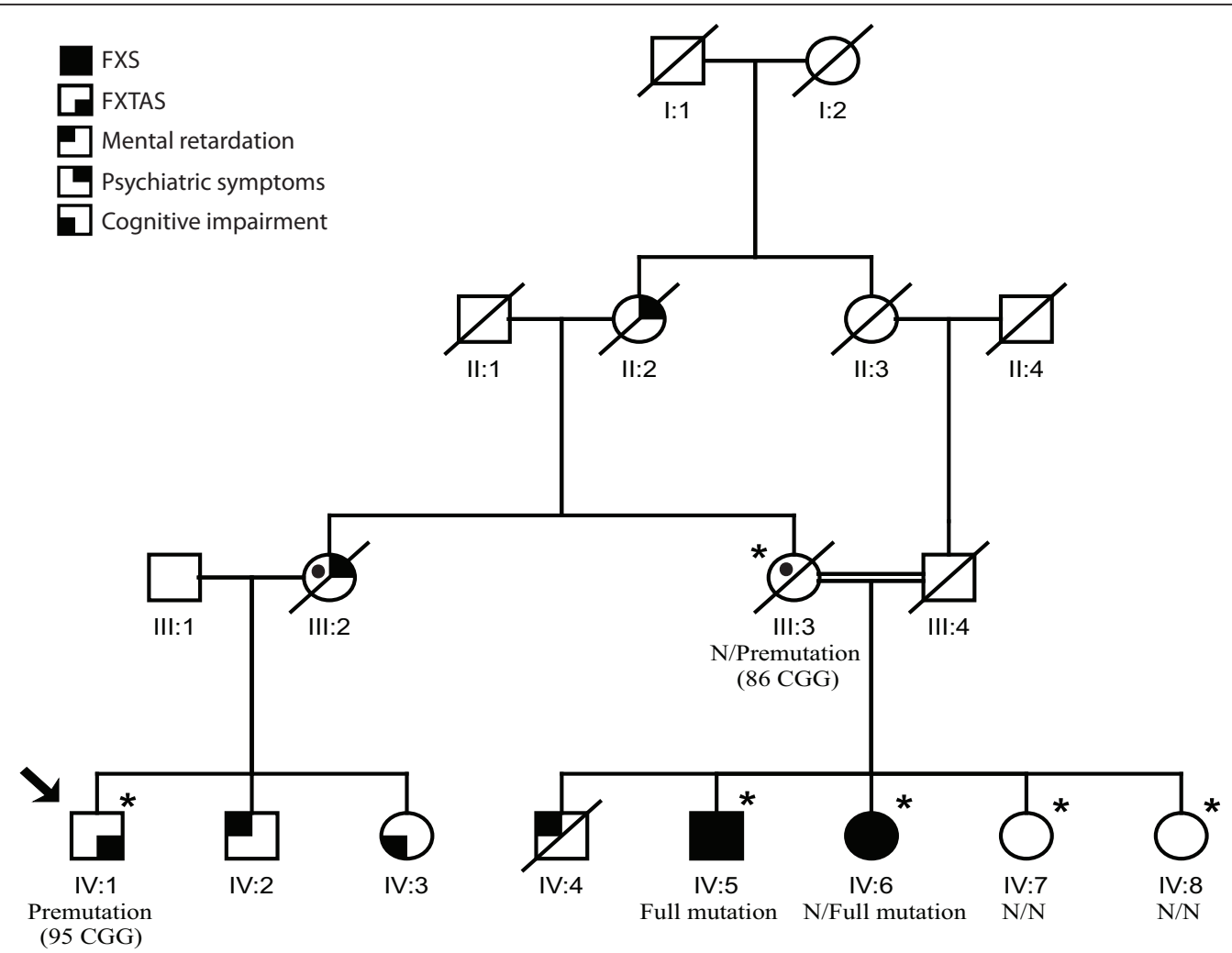

Figure 1 Family pedigree of the FXTAS patient. There is family history of mental retardation in males, and psychiatric disease in females. Individual IV:3 also presents tremor. Individual IV:4 died in infancy and was never tested for FXS. FMR1 repeat lengths are available for individuals marked with an asterisk. Symbols with the black circle are obligatory carriers of a FMR1 expanded allele. An arrow indicates the proband. (N, normal repeat size).

deficits. These clinical features and radiological findings confirmed a probable FXTAS diagnosis.

After identification of this FXTAS patient, we studied the family and discovered a clinical history of FXS (Figure 1) in two first cousins of the proband (IV:5 and IV:6). Information provided by the proband's son and by sisters of the FXS patients also suggests a history of psychiatric disease among premutation-transmitting females; III:2 had an admission to a psychiatric hospital. In addition, IV:3 was reported to have a tremor and cognitive deficits, but no neurological exam or DNA were available. Consanguinity was present in the family, thus increasing the risk for genetic diseases. No additional information was obtained for this family. Two patients carrying 'grey zone' alleles of 49 and 52 repeats (a frequency of $2.3 \%$ in the total sample) were also found. In the general population, the frequency of grey zone alleles is $3-4 / 100$ males $[16,19]$.

This study presents the first FXTAS screening in the Portuguese population of males with adult-onset movement disorders sent for genetic testing. The frequency of FMR1 premutations was $1.9 \%(1 / 54)$ in patients with ataxia as the cardinal clinical feature, which is within the range reported by multiple studies ( $0 \%$ to $4.1 \%)$, and $1.2 \%(1 / 86)$ in our global sample. A review of all such studies (Table 2) shows that the FMR1 premutation rate among men with cerebellar syndromes averages $1.2 \%$. Ascertainment of subjects, criteria used and the population studied may explain some of the frequency variability. As ascertainment via test request for SCA could fail to detect other FXTAS cases, we also included individuals referred for testing for PD and HD. We also applied stringent criteria, as only males with onset above age 50 years and no suggestive family history of late-onset movement disorders were included. However, we found no FMR1 premutations in 32 patients with a movement disorder other than ataxia, which is consistent with the literature (Table 2 ). Only 3 premutation carriers (a rate of $0.3 \%$ ) have been found in movement disorder cohorts that exclude ataxia cases - two had an initial diagnosis of multisystem atrophy (important in the differential diagnosis of ataxia), while the other was referred for HD testing.

Our study provides further evidence that a primary diagnosis of cerebellar ataxia is still the cardinal feature of the vast majority of FXTAS cases. There has been 
Table 2 Frequency of FMR1 premutations among male patients with adult-onset movement disorders

\begin{tabular}{|c|c|c|c|c|}
\hline Sample origin & Ascertainment via & Inclusion criteria & $\begin{array}{l}\text { Premutation } \\
\text { rate }\end{array}$ & Study \\
\hline United Kingdom & Referral for genetic test of SCA & Ataxia & $2 / 59$ & $\begin{array}{l}\text { (Macpherson et al., 2003) } \\
\text { [23] }\end{array}$ \\
\hline USA & Clinical diagnosis of ET & ET & $0 / 40$ & $\begin{array}{l}\text { (Garcia Arocena et al., 2004) } \\
\text { [24] }\end{array}$ \\
\hline USA & Clinical diagnosis of MSA & MSA & $0 / 40$ & (Garland et al., 2004) [25] \\
\hline USA & Referral for genetic test of SCA & Ataxia; age $>50$ & $1 / 167$ & $\begin{array}{l}\text { (Milunsky and Maher 2004) } \\
\text { [26] }\end{array}$ \\
\hline \multirow[t]{4}{*}{ Singapore } & $\begin{array}{l}\text { Clinical diagnosis of movement } \\
\text { disorder }\end{array}$ & $\mathrm{ET} ;$ age $>45$ & $0 / 34$ & (Tan et al., 2004) [27] \\
\hline & & Ataxia; isolated & $0 / 30$ & \\
\hline & & MSA & $0 / 12$ & \\
\hline & & APD & $0 / 15$ & \\
\hline Japan & Clinical diagnosis of MSA & MSA & $0 / 36$ & (Yabe et al., 2004) [28] \\
\hline Germany & Referral for genetic test of SCA & Ataxia; $\mathrm{AOO}>50$ & $0 / 269$ & (Zuhlke et al., 2004) [29] \\
\hline \multirow[t]{2}{*}{ Europe (mixed) } & Clinical diagnosis of MSA or related & MSA & $0 / 76$ & (Biancalana et al., 2005) [30] \\
\hline & & Ataxia & $1 / 19$ & \\
\hline Italy & Clinical diagnosis of SCA & Ataxia & $6 / 275$ & (Brussino et al., 2005) [31] \\
\hline Europe (mixed) & Clinical diagnosis of MSA & $M S A^{*}$ & $2 / 253$ & (Kamm et al., 2005) [32] \\
\hline \multirow[t]{2}{*}{ USA } & $\begin{array}{l}\text { Referral for genetic test of SCA and } \\
\mathrm{HD}\end{array}$ & Cerebellar disease & $1 / 73$ & (Seixas et al., 2005) [18] \\
\hline & & Basal ganglia disease & $0 / 6$ & \\
\hline Mixed & Clinical diagnosis of PD & PD & $0 / 414$ & (Toft et al., 2005) [33] \\
\hline Belgium & Referral for genetic test of SCA & Ataxia; age $>50$ & $5 / 122$ & (Van Esch et al., 2005) [34] \\
\hline Spain & Clinical diagnosis of SCA & Ataxia; isolated; age $>45$ & $1 / 87$ & $\begin{array}{l}\text { (Rodriguez-Revenga et al., } \\
\text { 2007) [35] }\end{array}$ \\
\hline USA & Referral for genetic test of SCA & Ataxia; age $>50$ & $1 / 286$ & (Adams et al., 2008) [17] \\
\hline Poland & Clinical diagnosis of SCA & Ataxia; age $>50$ & $1 / 178$ & (Rajkiewicz et al., 2008) [36] \\
\hline Brazil & $\begin{array}{l}\text { Clinical diagnosis of movement } \\
\text { disorder }\end{array}$ & $\begin{array}{l}\text { Ataxia, and/or tremor, and/or } \\
\text { parkinsonism; age }>45\end{array}$ & $0 / 66$ & (Reis et al., 2008) [37] \\
\hline Spain & Referral for genetic test of HD & $\mathrm{HD}$ & $1 / 95$ & $\begin{array}{l}\text { (Rodriguez-Revenga et al., } \\
\text { 2008) [38] }\end{array}$ \\
\hline United Kingdom & Clinical diagnosis of SCA & Ataxia & 0/105 & (Wardle et al., 2009) [39] \\
\hline \multirow[t]{2}{*}{ Portugal } & $\begin{array}{l}\text { Referral for genetic test of SCA, HD, } \\
\text { and PD }\end{array}$ & Ataxia; isolated; $\mathrm{AOO}>50$ & $1 / 54$ & This study \\
\hline & & Tremor or cognitive decline & $0 / 32$ & \\
\hline \multicolumn{2}{|l|}{$\begin{array}{l}\text { Total of ataxia } \\
\text { referrals }\end{array}$} & & $20 / 1724$ & \\
\hline \multicolumn{2}{|c|}{ Total of movement disorder referrals (other than ataxia) } & & $3 / 1119$ & \\
\hline
\end{tabular}

SCA, spinocerebellar ataxia; ET, essential tremor; MSA, multisystem atrophy; PD, Parkinson disease; APD, atypical Parkinson disease; AOO, age of onset. *Includes proven, possible, and probable MSA

debate as to whether genetic testing for FXTAS should be included in screening panels for late-onset movement disorders. We conclude that, though the prevalence of FXTAS appears low, genetic testing should be made available to patients with late-onset movement disorders, particularly with a clinical diagnosis of ataxia, and in agreement with the guidelines suggested by Berry-Kravis et al. [9].

FXTAS appears to be quite rare among women carrying premutations, but a recent study describes a higher rate of neuropsychiatric symptoms among daughters of
FXTAS patients, including memory and balance problems, tremor, and psychiatric disturbances [20]. Motor and mental dysfunction was recently reported in a FXTAS premutation carrier in a mother-daughter transmission [21]. Another study identified a high lifetime risk of mood and anxiety disorders among male and female carriers of the FMR1 premutation [22]. These findings concur with our observation that, in the family of the Portuguese FXTAS patient, there is an increased risk for motor and/or mental dysfunction in relatives carrying the premutation. 
In light of this, and given the complex phenotypic expression of the FMR1 expansions, psychological and neurologic surveillance (in addition to screening for POI in females) may be necessary for relatives of FXS and FXTAS patients, and perhaps for carriers in general. The complex inheritance and wide spectrum of phenotypes associated with the FMR1 (CGG) $)_{\mathrm{n}}$ reinforces the importance of genetic counseling in these families.

\section{Acknowledgements}

We would like to thank the patients and their families for participating in the study, and E. Cruz, A.M. Lopes, V. Mendes, and J. Cerqueira for technical assistance. This work was supported by research grant PIC/IC/82897/2007, FCT (Fundação para a Ciência e Tecnologia) and co-funded by FEDER. A.I.S. was the recipient of a scholarship from FCT (SFRH/BD/30702/2006). The experiments performed complied with the currently accepted ethical norms and national laws.

\section{Author details}

${ }^{1}$ UnIGENe, IBMC - Instituto de Biologia Molecular e Celular, Universidade do Porto, Porto, Portugal. ${ }^{2}$ Department of Neurology, Hospital de Egas Moniz, Lisboa, Portugal. ${ }^{3}$ Centro de Genética Médica Dr. Jacinto Magalhães, INSA, Porto, Portugal. ${ }^{4}$ Department of Neurology, Hospital de São Sebastião, Feira, Portugal. ${ }^{5}$ Division of Neurobiology, Department of Psychiatry, Johns Hopkins University School of Medicine, Baltimore, USA. ${ }^{6}$ ICBAS, Universidade do Porto, Portugal.

\section{Authors' contributions}

Study concept and design: AIS and IS. Acquisition of data: AIS, JV, IM, RS, IA, AMF, JPB and PC. Critical revision of the manuscript for important intellectual content: AIS, RLM, JS and IS. Study supervision: IS. All authors read and approved the final manuscript.

\section{Competing interests}

The author declares that they have no competing interests.

Received: 3 March 2011 Accepted: 3 June 2011 Published: 3 June 2011

\section{References}

1. Ashley CT Jr, Warren ST: Trinucleotide repeat expansion and human disease. Annu Rev Genet 1995, 29:703-728.

2. Verkerk AJ, Pieretti M, Sutcliffe JS, Fu YH, Kuhl DP, Pizzuti A, Reiner O, Richards S, Victoria MF, Zhang FP, Eussen BE, van Ommen GB, Blonden LAJ, Riggins GJ, Chastain JL, Kunst CB, Galjaard H, Caskey CT, Nelson DL, Oostra BA, Warren ST: Identification of a gene (FMR-1) containing a CGG repeat coincident with a breakpoint cluster region exhibiting length variation in fragile X syndrome. Cell 1991, 65:905-914.

3. Pieretti M, Zhang FP, Fu YH, Warren ST, Oostra BA, Caskey CT, Nelson DL: Absence of expression of the FMR-1 gene in fragile $\mathrm{X}$ syndrome. Cell 1991, 66:817-822.

4. Maddalena A, Richards CS, McGinniss MJ, Brothman A, Desnick RJ, Grier RE, Hirsch B, Jacky P, McDowell GA, Popovich B, Watson M, Wolff DJ: Technical standards and guidelines for fragile $X$ : the first of a series of diseasespecific supplements to the Standards and Guidelines for Clinical Genetics Laboratories of the American College of Medical Genetics. Quality Assurance Subcommittee of the Laboratory Practice Committee. Genet Med 2001, 3:200-205.

5. Sullivan AK, Marcus M, Epstein MP, Allen EG, Anido AE, Paquin JJ, YadavShah M, Sherman SL: Association of FMR1 repeat size with ovarian dysfunction. Hum Reprod 2005, 20:402-412.

6. Hagerman RJ, Leehey M, Heinrichs W, Tassone F, Wilson R, Hills J, Grigsby J, Gage B, Hagerman PJ: Intention tremor, parkinsonism, and generalized brain atrophy in male carriers of fragile $X$. Neurology 2001, 57:127-130.

7. Garcia Arocena D, Breece KE, Hagerman PJ: Distribution of CGG repeat sizes within the fragile $X$ mental retardation 1 (FMR1) homologue in a non-human primate population. Hum Genet 2003, 113:371-376.
8. Hagerman RJ, Hall DA, Coffey S, Leehey M, Bourgeois J, Gould J, Zhang L, Seritan A, Berry-Kravis E, Olichney J, Miller JW, Fong AL, Carpenter R, Bodine C, Gane LW, Rainin E, Hagerman H, Hagerman PJ: Treatment of fragile $\mathrm{X}$-associated tremor ataxia syndrome (FXTAS) and related neurological problems. Clin Interv Aging 2008, 3:251-262.

9. Berry-Kravis E, Abrams L, Coffey SM, Hall DA, Greco C, Gane LW, Grigsby J, Bourgeois JA, Finucane B, Jacquemont S, Brunberg JA, Zhang L, Lin J, Tassone F, Hagerman PJ, Hagerman RJ, Leehey MA: Fragile X-associated tremor/ataxia syndrome: clinical features, genetics, and testing guidelines. Mov Disord 2007, 22:2018-2030.

10. Jacquemont S, Hagerman RJ, Leehey M, Grigsby J, Zhang L, Brunberg JA, Greco C, Des Portes V, Jardini T, Levine R, Berry-Kravis E, Brown WT, Schaeffer S, Kissel J, Tassone F, Hagerman PJ: Fragile X premutation tremor/ataxia syndrome: molecular, clinical, and neuroimaging correlates. Am J Hum Genet 2003, 72:869-878.

11. Hagerman PJ, Hagerman RJ: The fragile-X premutation: a maturing perspective. Am J Hum Genet 2004, 74:805-816.

12. Greco CM, Hagerman RJ, Tassone F, Chudley AE, Del Bigio MR, Jacquemont S, Leehey M, Hagerman PJ: Neuronal intranuclear inclusions in a new cerebellar tremor/ataxia syndrome among fragile $\mathrm{X}$ carriers. Brain 2002, 125:1760-1771.

13. Tassone F, Iwahashi C, Hagerman PJ: FMR1 RNA within the intranuclear inclusions of fragile $\mathrm{X}$-associated tremor/ataxia syndrome (FXTAS). RNA Biol 2004, 1:103-105.

14. Hagerman RJ, Leavitt BR, Farzin F, Jacquemont $S$, Greco CM, Brunberg JA, Tassone F, Hessl D, Harris SW, Zhang L, Jardini T, Gane LW, Ferranti J, Ruiz L, Leehey MA, Grigsby J, Hagerman PJ: Fragile-X-associated tremor/ataxia syndrome (FXTAS) in females with the FMR1 premutation. Am J Hum Genet 2004, 74:1051-1056.

15. Jacquemont S, Hagerman RJ, Leehey MA, Hall DA, Levine RA, Brunberg JA, Zhang L, Jardini T, Gane LW, Harris SW, Herman K, Grigsby J, Greco CM, Berry-Kravis E, Tassone F, Hagerman PJ: Penetrance of the fragile Xassociated tremor/ataxia syndrome in a premutation carrier population. Jama 2004, 291:460-469.

16. Crawford DC, Meadows KL, Newman JL, Taft LF, Pettay DL, Gold LB, Hersey SJ, Hinkle EF, Stanfield ML, Holmgreen P, Yeargin-Allsopp M, Boyle C, Sherman SL: Prevalence and phenotype consequence of FRAXA and FRAXE alleles in a large, ethnically diverse, special education-needs population. Am J Hum Genet 1999, 64:495-507.

17. Adams SA, Steenblock K, Thibodeau SN, Lindor NM: Premutations in the FMR1 gene are uncommon in men undergoing genetic testing for spinocerebellar ataxia. J Neurogenet 2008, 22:77-92.

18. Seixas Al, Maurer MH, Lin M, Callahan C, Ahuja A, Matsuura T, Ross CA, Hisama FM, Silveira I, Margolis RL: FXTAS, SCA10, and SCA17 in American patients with movement disorders. Am J Med Genet A 2005, 136:87-89.

19. Patsalis PC, Sismani C, Hettinger JA, Holden JJ, Lawson JS, Chalifoux M, Wing M, Walker M, Leggo J: Frequencies of "grey-zone" and premutationsize FMR1 CGG-repeat alleles in patients with developmental disability in Cyprus and Canada. Am J Med Genet 1999, 84:195-197.

20. Chonchaiya W, Nguyen DV, Au J, Campos L, Berry-Kravis EM, Lohse K, Mu Y, Utari A, Hervey C, Wang L, Sorensen P, Cook K, Gane L, Tassone F, Hagerman RJ: Clinical involvement in daughters of men with fragile $X$ associated tremor ataxia syndrome. Clin Genet 2010, 78:38-46.

21. Rodriguez-Revenga L, Pagonabarraga J, Gomez-Anson B, Lopez-Mourelo O, Madrigal I, Xuncla M, Kulisevsky J, Mila M: Motor and mental dysfunction in mother-daughter transmitted FXTAS. Neurology 2010, 75:1370-1376.

22. Bourgeois JA, Seritan AL, Casillas EM, HessI D, Schneider A, Yang Y, Kaur I, Cogswell JB, Nguyen DV, Hagerman RJ: Lifetime prevalence of mood and anxiety disorders in fragile x premutation carriers. J Clin Psychiatry 2011, 72:175-82.

23. Macpherson J, Waghorn A, Hammans S, Jacobs P: Observation of an excess of fragile-X premutations in a population of males referred with spinocerebellar ataxia. Hum Genet 2003, 112:619-620.

24. Garcia Arocena D, Louis ED, Tassone F, Gilliam TC, Ottman R, Jacquemont S, Hagerman PJ: Screen for expanded FMR1 alleles in patients with essential tremor. Mov Disord 2004, 19:930-933.

25. Garland EM, Vnencak-Jones CL, Biaggioni I, Davis TL, Montine TJ, Robertson D: Fragile X gene premutation in multiple system atrophy. J Neurol Sci 2004, 227:115-118. 
26. Milunsky JM, Maher TA: Fragile $X$ carrier screening and spinocerebellar ataxia in older males. Am J Med Genet 2004, 125A:320.

27. Tan EK, Zhao Y, Puong KY, Law HY, Chan LL, Yew K, Tan C, Shen H, Chandran VR, Teoh ML, Yih Y, Pavanni R, Wong MC, Ng IS: Fragile X premutation alleles in SCA, ET, and parkinsonism in an Asian cohort. Neurology 2004, 63:362-363.

28. Yabe I, Soma H, Takei A, Fujik N, Sasaki H: No association between FMR1 premutations and multiple system atrophy. J Neurol 2004, 251:1411-1412.

29. Zuhlke C, Budnik A, Gehlken U, Dalski A, Purmann S, Naumann M, Schmidt M, Burk K, Schwinger E: FMR1 premutation as a rare cause of late onset ataxia-evidence for FXTAS in female carriers. J Neurol 2004, 251:1418-1419.

30. Biancalana V, Toft M, Le Ber I, Tison F, Scherrer E, Thibodeau S, Mandel JL, Brice A, Farrer MJ, Durr A: FMR1 premutations associated with fragile Xassociated tremor/ataxia syndrome in multiple system atrophy. Arch Neurol 2005, 62:962-966.

31. Brussino A, Gellera C, Saluto A, Mariotti C, Arduino C, Castellotti B, Camerlingo M, de Angelis V, Orsi L, Tosca P, Migone N, Taroni F, Brusco A: FMR1 gene premutation is a frequent genetic cause of late-onset sporadic cerebellar ataxia. Neurology 2005, 64:145-147.

32. Kamm C, Healy DG, Quinn NP, Wullner U, Moller JC, Schols L, Geser F, Burk K, Borglum AD, Pellecchia MT, Tolosa E, del Sorbo F, Nilsson C, Bandmann O, Sharma M, Mayer P, Gasteiger M, Haworth A, Ozawa T, Lees AJ, Short J, Giunti P, Holinski-Feder E, Illig T, Wichmann HE, Wenning GK, Wood NW, Gasser T, European Multiple System Atrophy Study Group: The fragile $\mathrm{X}$ tremor ataxia syndrome in the differential diagnosis of multiple system atrophy: data from the EMSA Study Group. Brain 2005, 128:1855-1860.

33. Toft M, Aasly J, Bisceglio G, Adler CH, Uitti RJ, Krygowska-Wajs A, Lynch T, Wszolek ZK, Farrer MJ: Parkinsonism, FXTAS, and FMR1 premutations. Mov Disord 2005, 20:230-233.

34. Van Esch H, Dom R, Bex D, Salden I, Caeckebeke J, Wibail A, Borghgraef M, Legius E, Fryns JP, Matthijs G: Screening for FMR-1 premutations in 122 older Flemish males presenting with ataxia. Eur I Hum Genet 2005, 13:121-123.

35. Rodriguez-Revenga L, Gomez-Anson B, Munoz E, Jimenez D, Santos M, Tintore M, Martin G, Brieva L, Mila M: FXTAS in spanish patients with ataxia: support for female FMR1 premutation screening. Mol Neurobiol 2007, 35:324-328.

36. Rajkiewicz M, Sulek-Piatkowska A, Krysa W, Zdzienicka E, Szirkowiec W, Zaremba J: Screening for premutation in the FMR1 gene in male patients suspected of spinocerebellar ataxia. Neurol Neurochir Pol 2008, 42:497-504.

37. Reis AH, Ferreira AC, Gomes KB, Aguiar MJ, Fonseca CG, Cardoso FE, Pardini VC, Carvalho MR: Frequency of FMR1 premutation in individuals with ataxia and/or tremor and/or parkinsonism. Genet Mol Res 2008, 7:74-84.

38. Rodriguez-Revenga L, Santos MM, Sanchez A, Pujol M, Gomez-Anson B, Badenas C, Jimenez D, Madrigal I, Mila M: Screening for FXTAS in 95 Spanish patients negative for Huntington disease. Genet Test 2008, 12:135-138.

39. Wardle M, Majounie E, Muzaimi MB, Williams NM, Morris HR, Robertson NP: The genetic aetiology of late-onset chronic progressive cerebellar ataxia. A population-based study. J Neurol 2009, 256:343-348.

doi:10.1186/1744-9081-7-19

Cite this article as: Seixas et al: FXTAS is rare among Portuguese patients with movement disorders: FMR1 premutations may be associated with a wider spectrum of phenotypes. Behavioral and Brain

Functions 2011 7:19.

\section{Submit your next manuscript to BioMed Central and take full advantage of:}

- Convenient online submission

- Thorough peer review

- No space constraints or color figure charges

- Immediate publication on acceptance

- Inclusion in PubMed, CAS, Scopus and Google Scholar

- Research which is freely available for redistribution

Submit your manuscript at www.biomedcentral.com/submit
Biomed Central 